\title{
Evaluasi Pertumbuhan dan Daya Hasil Empat Belas Cabai Hibrida
}

\author{
Growth and Yield Evaluation of Fourteen Chili Pepper Hybrids
}

\author{
Arya Widura Ritonga, Muhamad Syukur*, Sriani Sujiprihati, Arif Rahman Hakim
}

Departemen Agronomi dan Hortikultura, Fakultas Pertanian, Institut Pertanian Bogor

Jl. Meranti, Kampus IPB Darmaga, Bogor 16680, Indonesia

*Penulis untuk korespondensi. email: muhsyukur@ipb.ac.id

Diterima 11 November 2016/Disetujui 9 Januari 2017

\begin{abstract}
Planting chili pepper hybrid varieties offers an alternative strategy to fill the needs of chili pepper in Indonesia. The aim of the experiment was to evaluate and select fourteen chili pepper hybrids thus obtained chili peppers hybrid potential to be released as hybrid varieties. The experimental design was used Randomized Complete Block Design (RCBD) with one factor and three replications. Plant materials consist of fourteen chili pepper hybrid and one commercial hybrid of chili pepper. IPB CH-I produced higher selection index value than commercial hybrid of chili pepper. The IPB CH-I was potential to be released as hybrid variety of chili pepper.
\end{abstract}

Keywords: hybrid varieties, selection, selection index

\section{ABSTRAK}

Penanaman varietas cabai hibrida bisa menjadi strategi alternatif untuk mencukupi kebutuhan cabai di Indonesia. Penelitian ini bertujuan untuk mengevaluasi dan menseleksi 14 hibrida cabai yang potensial untuk dilepas sebagai varietas cabai hibrida. Rancangan percobaan yang digunakan adalah Rancangan Kelompok Lengkap Teracak (RKLT) satu faktor dengan tiga ulangan. Bahan tanaman yang digunakan pada percobaan ini terdiri dari 14 hibrida cabai uji dan 1 varietas komersial sebagai pembanding. Hanya hibrida cabai IPB CH-I yang memiliki nilai indeks seleksi yang lebih tinggi dibandingkan varietas pembanding. Hibrida cabai IPB CH-I merupakan hibrida cabai yang potensial untuk dapat dilepas sebagai varietas cabai hibrida.

Kata kunci: indeks seleksi, seleksi, varietas hibrida

\section{PENDAHULUAN}

Cabai termasuk salah satu tanaman sayuran terpenting di Indonesia. Luas areal penanaman cabai mencapai 254 ribu hektar pada tahun 2015 (BPS dan Dirjen Hortikultura, 2016) merupakan luasan terbesar pada komoditi sayuran. Namun, sering kali jumlah produksi cabai tidak mampu mencukupi kebutuhan permintaan pasar, sehingga menyebabkan tingginya harga cabai di pasaran. Harga cabai merah dan keriting pernah mencapai lebih dari Rp 87,000 $\mathrm{kg}^{-1}$ pada tahun 2016 (Kementerian Pertanian RI, 2016). Salah satu penyebab rendahnya produksi cabai adalah penggunaan benih unggul cabai yang masih rendah sehingga menyebabkan pertanaman cabai lebih mudah teserang hama penyakit dan produktivitasnya yang tidak optimal. Produktivitas rata-rata nasional cabai baru mencapai 8.65 ton ha ${ }^{-1}$ untuk cabai besar dan 6.45 ton ha $\mathrm{h}^{-1}$ untuk cabai rawit (BPS dan Dirjen Hortikultura, 2016). Produktivitas ini masih jauh dibawah potensinya yang dapat mencapai 20 ton ha $^{-1}$ (Syukur et al., 2010a).

Salah satu solusi yang dapat dilakukan adalah dengan penggunaan varietas cabai hibrida. Varietas cabai hibrida dinilai memiliki produktivitas yang lebih tinggi dibandingkan varietas cabai non hibrida. Hal ini karena cabai hibrida diduga memiliki nilai heterosis yang tinggi pada karakter daya hasil seperti pada tanaman menyerbuk silang. Nilai heterosis pada hasil persilangan dialel tanaman cabai dapat mencapai $63 \%$ dan nilai heterobeltiosisnya dapat mencapai 44\% (Sujiprihati et al., 2007), bahkan Mantri (2006) menyatakan bahwa nilai heterosis pada cabai dapat mencapai lebih dari $100 \%$.

Perakitan varietas cabai hibrida berdaya hasil tinggi dapat dilakukan baik melalui seleksi secara langsung terhadap karakter daya hasil maupun secara tidak langsung dengan menggunakan karakter lain yang terkait dengan daya hasil (Falconer dan Mackay, 1996). Seleksi menggunakan hanya satu karakter atau beberapa karakter sekaligus tidak mudah dilakukan. Metode seleksi indeks merupakan salah satu metode seleksi yang dikembangkan untuk para pemulia untuk dapat memilih genotipe unggul sesuai tujuan yang diinginkan (Hapsari, 2014). Metode seleksi berdasarkan indeks seleksi telah berhasil menyeleksi empat dari 34 genotipe kacang hijau yang memiliki hasil panen tinggi dan panen serempak (Sutjahjo et al., 2007). 
Penelitian ini bertujuan untuk mengevaluasi pertumbuhan dan daya hasil serta melakukan seleksi beberapa cabai hibrida dengan seleksi indeks dalam rangka memperoleh calon-calon cabai hibrida yang potensial untuk dilepas sebagai varietas cabai hibrida.

\section{METODE PENELITIAN}

Penelitian ini dilaksanakan di Kebun Percobaan IPB Cikabayan dan Laboratorium Pemuliaan Tanaman (Lab PMT), Departemen Agronomi dan Hortikultura, Fakultas Pertanian, Institut Pertanian Bogor. Lokasi penelitian ini berada pada ketinggian 230 meter di atas permukaan laut (dpl). Sebanyak 14 genotipe cabai hibrida (IPB CH-A, IPB CH-B, IPB CH-C, IPB CH-D, IPB CH-E, IPB CH-F, IPB CH-G, IPB CH-H, IPB CH-I, IPB CH-J, IPB CH-K, IPB CH$\mathrm{L}$, IPB CH-M, dan IPB CH-O) dan 1 varietas pembanding (Varietas Hot Chili) digunakan dalam penelitian ini.

Rancangan percobaan yang digunakan pada penelitian ini adalah Rancangan Kelompok Lengkap Teracak (RKLT) dengan satu faktor yang terdiri dari 15 taraf percobaan (genotipe). Penanaman setiap genotipe diulang sebanyak tiga kali sehingga dihasilkan 45 satuan percobaan. Setiap satuan percobaan ditanam sebanyak 20 tanaman dengan 10 tanaman digunakan sebagai tanaman sampel.

Penanaman dilakukan sesuai dengan budidaya standar untuk cabai. Benih disemai terlebih dahulu pada tray plastik sebanyak dua benih per lubang dengan media semai pupuk kandang dan arang sekam 1:1. Setelah bibit cabai berusia 4 minggu atau telah memiliki 4 daun sempurna, bibit cabai dipindahkan dan ditanam bedengan berukuran $5 \mathrm{~m}$ x $1 \mathrm{~m}$ dengan jarak tanam $0.5 \mathrm{~m}$ x $0.5 \mathrm{~m}$. Pemupukan diberikan satu minggu sekali dengan menggunakan pupuk kocor NPK mutiara 16-16-16 dengan konsentrasi $5 \mathrm{~g} \mathrm{~L}^{-1}$ pada fase vegetatif dan $10 \mathrm{~g} \mathrm{~L}^{-1}$ pada fase generatif dengan dosis 240 g per lubang tanam. Penyemprotan pestisida juga dilakukan setiap minggu setelah tanam dengan insektisida, fungisida, bakterisida dan akarisida secara bergantian dengan dosis sesuai anjuran. Pemeliharaan lainnya yang dilakukan adalah penyiangan, pengikatan dan pewiwilan yang dilakukan setiap minggu.

Karakter yang diamati pada penelitian ini terdiri atas tinggi tanaman $(\mathrm{cm})$, tinggi dikotomus $(\mathrm{cm})$, lebar tajuk (cm), diameter batang ( $\mathrm{mm})$, umur berbunga (HST), umur panen (HST), panjang buah $(\mathrm{cm})$, diameter buah $(\mathrm{mm})$, bobot per buah $(\mathrm{g})$, jumlah buah per tanaman, jumlah buah layak pasar, bobot buah per tanaman $(\mathrm{g})$, dan bobot buah per tanaman layak pasar (g). Analisis ragam dilakukan pada setiap karakter tersebut. Jika hasil analisis ragam menunjukkan perbedaan yang nyata maka akan dilakukan uji lanjut Dunnet's pada taraf 5\%. Seleksi terhadap cabai hibrida dilakukan dengan indeks seleksi yang mengacu pada Falconer dan Mackay (1996). Faktor pembobot (FS) digunakan pada perhitungan indeks seleksi berbeda-beda antar karakter pengamatan.

\section{HASIL DAN PEMBAHASAN}

Hasil rekapitulasi sidik ragam menujukkan genotipe berpengaruh sangat nyata terhadap semua karakter pengamatan (Tabel 1). Hal ini menunjukkan bahwa baik karakter pertumbuhan maupun karakter daya hasil cabai sangat dipengaruhi oleh genotipe. Syukur et al., (2010b) melaporkan bahwa genotipe berpengaruh sangat nyata pada karakter daya hasil cabai hibrida.

\section{Umur Berbunga dan Umur Panen Cabai Hibrida}

Hasil pengamatan menunjukkan bahwa hampir seluruh cabai hibrida yang diuji memiliki umur berbunga

Tabel 1. Rekapitulasi F hitung dan koefisien keragaman pada beberapa karakter cabai hibrida yang diamati

\begin{tabular}{llccc}
\hline \multirow{2}{*}{ No } & Karakter & & Genotipe & KK $(\%)$ \\
\cline { 2 - 4 } & & F-hitung & Peluang & 9,97 \\
2 & Tinggi tanaman & $2,86^{* *}$ & 0,00 & 11,17 \\
3 & Tinggi dikotomus & $4,19^{* *}$ & 0,00 & 10,51 \\
4 & Debartajuk & $4,77^{* *}$ & 0,00 & 10,42 \\
5 & Umurberbunga & $6,25 * *$ & 0,00 & 10,50 \\
6 & Umurpanen & $8,60^{* *}$ & 0,00 & 4,46 \\
7 & Panjangbuah & $48,67 * *$ & 5,00 & 5,92 \\
8 & Diameter buah & $56,93^{* *}$ & 0,00 & 6,93 \\
9 & Bobotper buah & $20,91^{* *}$ & 0,00 & 12,78 \\
10 & Jumlahbuah per tananaman & $36,13^{* *}$ & 0,00 & 24,81 \\
11 & Jumlahbuahlayakpasar & $7,76^{* *}$ & 0,00 & 24,67 \\
12 & Bobotbuah per tanaman & $9,31^{* *}$ & 0,00 & 31,44 \\
13 & Bobotbuah per tanaman layak pasar & $4,93^{* *}$ & 0,00 & 32,18 \\
\hline
\end{tabular}

Keterangan: **= berbeda sangat nyata pada taraf $1 \%$ 
yang tidak berbeda nyata dengan varietas pembanding (Tabel 2). Umur berbunga varietas yang diuji sebagian besar berkisar antara 28-34 HST dan hanya cabai hibrida $\mathrm{CH}-\mathrm{O}$ yang memiliki umur berbunga lebih lambat dibandingkan varietas pembanding.

Sementara itu, hasil pengamatan juga menunjukkan bahwa terdapat 4 cabai hibrida uji (IPB $\mathrm{CH}-\mathrm{B}$, IPB $\mathrm{CH}-$ E, IPB CH-E, dan IPB CH-F ) yang memiliki umur panen lebih cepat dibandingkan varietas pembanding, sedangkan cabai hibrida uji lainnya memiliki umur panen yang tidak berbeda nyata dengan varietas pembanding (Tabel 2). Umur panen yang cepat merupakan salah satu sifat keunggulan dari varietas cabai karena semakin cepat umur panen maka akan semakin sedikit terpaan cekaman baik biotik maupun abiotik di lahan sehingga tanaman dapat berproduksi secara maksimal. Umur panen yang genjah dapat meningkatkan indeks pertanaman dan menghindari kegagalan panen akibat cekaman biotik dan abiotik (Mejaya et al., 2010).

\section{Karakter Pertumbuhan Tanaman Cabai Hibrida}

Hasil pengamatan terhadap karakter pertumbuhan menunjukkan bahwa hampir seluruh cabai hibrida yang diuji memiliki tinggi tanaman yang tidak berbeda nyata dengan varietas pembanding kecuali cabai hibrida CH-D memiliki tinggi tanaman yang lebih rendah dibandingkan varietas pembanding dan cabai hibrida uji lainnya (Tabel 3). Sedangkan cabai hibrida $\mathrm{CH}-\mathrm{O}$ memilki tinggi dikotomus yang lebih tinggi dibandingkan varietas pembanding dan cabai hibrida lainnya (Tabel 3). Hal ini sangat menguntungkan karena dengan tinggi dikotomus yang tinggi dapat menghindarkan buah dari cipratan air dari tanah yang

Tabel 2. Nilai rataan umur berbunga dan umur panen

\begin{tabular}{lcc}
\hline \multirow{2}{*}{ Genotipe } & Umur berbunga & Umur panen \\
\cline { 2 - 3 } & $(\mathrm{HST})$ & $(\mathrm{HST})$ \\
\hline IPB CH-A & 29,33 & 82,00 \\
IPB CH-B & 21,67 & $66,67^{*}$ \\
IPB CH-C & 30,00 & $75,00^{*}$ \\
IPB CH-D & 31,33 & 77,33 \\
IPB CH-E & 27,33 & $75,00^{*}$ \\
IPB CH-F & 31,33 & $75,00^{*}$ \\
IPB CH-G & 31,67 & 79,67 \\
IPB CH-H & 28,33 & 79,67 \\
IPB CH-I & 28,67 & 82,00 \\
IPB CH-J & 30,00 & 79,67 \\
IPB CH-K & 31,67 & 79,67 \\
IPB CH-L & 34,67 & 84,33 \\
IPB CH-M & 31,33 & 86,67 \\
IPB CH-O & $48,00^{*}$ & $133,33^{*}$ \\
Hot Chilli & 29,33 & 84,33 \\
\hline
\end{tabular}

Keterangan: * = berbeda nyata terhadap varietas pembanding (Dunnet's taraf $5 \%$ ) dapat mengurangi potensi serangan penyakit antaknosa. Dikotomus yang pendek menyebabkan buah cabai dapat bersentuhan dengan mulsa atau tanah dan rawan terkena percikan air hujan langsung yang dapat menyebabkan penyakit pada buah (Rommahdi et al., 2015). Namun demikian, genotipe cabai yang memiliki tinggi tanaman dan tinggi dikotomus yang telalu tinggi kemungkinan akan lebih mudah rebah karena angin (Grinberg et al., 2005)

Hasil pengamatan lainnya menunjukkan bahwa sebagian besar cabai hibrida yang diuji memiliki lebar tajuk yang tidak berbeda nyata dengan varietas pembanding kecuali cabai hibrida $\mathrm{CH}-\mathrm{D}$ dan $\mathrm{CH}-\mathrm{O}$ yang menghasilkan lebar tajuk yang lebih rendah dibandingkan varietas pembanding (Tabel 3). Sementara itu, cabai hibrida $\mathrm{CH}-\mathrm{B}, \mathrm{CH}-\mathrm{H}, \mathrm{CH}-\mathrm{I}, \mathrm{CH}-$ $\mathrm{K}$, $\mathrm{CH}-\mathrm{L}$, dan $\mathrm{CH}-\mathrm{M}$ memiliki diameter batang yang tidak berbeda nyata dengan varietas pembanding dan lebih besar dibandingkan cabai hibrida uji lainnya (Tabel 3). Diameter batang yang besar menjadikan tanaman dapat lebih kokoh menopang buah dan tanaman sehingga menjdaikan tanaman lebih tahan rebah. Karakter diameter batang yang besar memberikan keuntungan terhadap pertumbuhan vegetatif dan generatif, karena tanaman menjadi lebih kokoh dan tidak mudah rebah (Suntoyo et al., 2015).

\section{Karakter Buah Cabai Hibrida}

Hasil pengamatan terhadap karakter buah menunjukkan bahwa seluruh cabai hibrida yang diuji memiliki bobot buah yang lebih rendah dibandingkan varietas pembanding (Tabel 4). Hal ini sangat merugikan tentunya karena karakter bobot per buah umumnya memiliki korelasi yang positif terhadap karakter produktivitas pada tanaman cabai. Yunianti et al., (2010) melaporkan bahwa karakter bobot buah memiliki korelasi positif yang sangat nyata terhadap karakter produksi cabai.

Sementara itu, cabai hibrida IPB CH-A, IPB CH-G, IPB $\mathrm{CH}-\mathrm{H}$, dan IPB $\mathrm{CH}-\mathrm{L}$ memiliki panjang buah yang tidak berbeda nyata dengan varietas pembanding dan lebih panjang dibandingkan cabai hibrida uji lainnya. Sedangkan untuk karakter diameter buah, hanya cabai hibrida $\mathrm{CH}$ I dan CH-M yang memiliki diameter buah yang setara dengan varietas pembanding (Tabel 4). Syukur et al., (2012) memaparkan bahwa salah satu spesifikasi buah cabai untuk industri saus tertentu adalah memiliki diameter pangkal buah antara $1,00-1,70 \mathrm{~cm}$.

\section{Karakter Daya Hasil Cabai Hibrida}

Pengamatan terhadap karakter daya hasil menunjukkan bahwa cabai hibrida $\mathrm{CH}-\mathrm{B}, \mathrm{CH}-\mathrm{E}, \mathrm{CH}-\mathrm{F}$ dan $\mathrm{CH}-\mathrm{K}$ memiliki jumlah buah per tanaman dan jumlah buah layak pasar yang lebih tinggi dibandingkan varietas pembanding dan cabai hibrida uji lainnya (Tabel 5). Jumlah buah umumnya memiliki pengaruh langsung yang tinggi terhadap karakter bobot buah per tanaman. Syukur et al., (2010b) melaporkan bahwa karakter jumlah buah per tanaman memilki pengaruh langsung yang paling besar terhadap karakter bobot buah per tanaman pada tanaman cabai yaitu sebesar 0.78 . Daryanto et al. (2010) juga melaporkan bahwa terdapat korelasi yang 
Comm. Hort. J, Februari 2017, 1(1):20-25

Tabel 3. Nilai rataan tinggi tanaman, tinggi dikotomus, lebar tajuk dan diameter batang

\begin{tabular}{|c|c|c|c|c|}
\hline Genotipe & $\begin{array}{c}\text { Tinggi tanaman } \\
(\mathrm{cm})\end{array}$ & $\begin{array}{l}\text { Tinggi dikotomus } \\
(\mathrm{cm})\end{array}$ & $\begin{array}{c}\text { Lebar tajuk } \\
(\mathrm{cm})\end{array}$ & $\begin{array}{c}\text { Diameter batang } \\
(\mathrm{mm})\end{array}$ \\
\hline IPB CH-A & 63,69 & 22,23 & 69,64 & $11,80^{*}$ \\
\hline IPB CH-B & 62,77 & 21,84 & 70,44 & 13,32 \\
\hline IPB CH-C & 64,67 & 22,41 & 65,85 & $13,16^{*}$ \\
\hline IPB CH-D & $53,08^{*}$ & 23,03 & $47,76^{*}$ & $8,57^{*}$ \\
\hline IPB CH-E & 57,81 & 20,61 & 70,19 & $12,47 *$ \\
\hline IPB CH-F & 68,31 & 19,89 & 67,87 & $11,51^{*}$ \\
\hline IPB CH-G & 57,17 & 19,21 & 65,27 & $12,09 *$ \\
\hline IPB CH-H & 70,51 & 23,91 & 80,78 & 14,17 \\
\hline IPB CH-I & 74,67 & 23,16 & 78,72 & 13,78 \\
\hline IPB CH-J & 67,65 & 26,02 & 57,76 & $9,73^{*}$ \\
\hline IPB CH-K & 58,58 & 20,22 & 70,79 & 13,65 \\
\hline IPB CH-L & 60,30 & 20,41 & 74,17 & 13,83 \\
\hline IPB CH-M & 64,86 & 26,11 & 73,77 & 14,46 \\
\hline IPB CH-O & 73,06 & $30,68 *$ & $52,88^{*}$ & $12,75^{*}$ \\
\hline Hot Chilli & 68,09 & 24,05 & 70,49 & 16,51 \\
\hline
\end{tabular}

Keterangan: * = berbeda nyata terhadap varietas pembanding (Dunnet's taraf $5 \%$ )

Tabel 4. Nilai rataan bobot buah, panjang buah, dan diameter buah

\begin{tabular}{lccc}
\hline Genotipe & $\begin{array}{c}\text { Bobot per buah } \\
(\mathrm{g})\end{array}$ & $\begin{array}{c}\text { Panjang buah } \\
(\mathrm{cm})\end{array}$ & $\begin{array}{c}\text { Diameter buah } \\
(\mathrm{mm})\end{array}$ \\
\hline IPB CH-A & $8,96^{*}$ & 10,95 & $12,22^{*}$ \\
IPB CH-B & $7,26^{*}$ & $10,22^{*}$ & $9,38^{*}$ \\
IPB CH-C & $6,12^{*}$ & $8,85^{*}$ & $9,83^{*}$ \\
IPB CH-D & $2,80^{*}$ & $5,78^{*}$ & $8,23^{*}$ \\
IPB CH-E & $3,80^{*}$ & $7,26^{*}$ & $8,65^{*}$ \\
IPB CH-F & $3,21^{*}$ & $6,40^{*}$ & $8,71^{*}$ \\
IPB CH-G & $7,20^{*}$ & 11,27 & $10,62^{*}$ \\
IPB CH-H & $6,63^{*}$ & 10,76 & $10,96^{*}$ \\
IPB CH-I & $7,81^{*}$ & $9,57^{*}$ & 13,49 \\
IPB CH-J & $3,41^{*}$ & $5,78^{*}$ & $9,16^{*}$ \\
IPB CH-K & $7,11^{*}$ & $9,58^{*}$ & $10,33^{*}$ \\
IPB CH-L & $8,77^{*}$ & 11,08 & $11,65^{*}$ \\
IPB CH-M & $8,68^{*}$ & $10,25^{*}$ & 13,56 \\
IPB CH-O & $1,90^{*}$ & $4,76^{*}$ & $7,94^{*}$ \\
Hot Chilli & 11,86 & 12,03 & 15,04 \\
\hline
\end{tabular}

Keterangan: * = berbeda nyata terhadap varietas pembanding (Dunnet's taraf $5 \%$ )

nyata dan positif antara karakter jumlah buah dan bobot buah per tanaman pada cabai besar.

Hasil pengamatan terhadap karakter hasil juga menunjukkan bahwa seluruh cabai hibrida yang diuji (kecuali IPB CH-D dan CH-O) memiliki bobot buah per tanaman dan bobot buah layak pasar yang setara dengan varietas pembanding (Tabel 5). Hal ini mengindikasikan bahwa sebagian besar hibrida yang uji telah layak untuk dilepas sebagai varietas hibrida komersial berdasarkan karakter bobot buah per tanaman dan bobot buah layak pasar. 
Tabel 5. Nilai rataan jumlah buah layak pasar, bobot buah layak pasar, jumlah buah per tanaman dan bobot buah per tanaman

\begin{tabular}{lcccc}
\hline Genotipe & $\begin{array}{c}\text { Jumlah buah layak } \\
\text { pasar }\end{array}$ & $\begin{array}{c}\text { Jumlah buah per } \\
\text { tanaman }\end{array}$ & $\begin{array}{c}\text { Bobot buah layak } \\
\text { pasar } \\
(\mathrm{g})\end{array}$ & $\begin{array}{c}\text { Bobot buah per } \\
\text { tanaman } \\
(\mathrm{g})\end{array}$ \\
\hline IPB CH-A & 41,07 & 88,07 & 262,58 & 384,56 \\
IPB CH-B & $74,13^{*}$ & $107,20^{*}$ & 234,18 & 294,08 \\
IPB CH-C & 48,80 & 66,93 & 282,03 & 319,49 \\
IPB CH-D & 50,23 & 63,54 & $83,46^{*}$ & $95,86^{*}$ \\
IPB CH-E & $98,33^{*}$ & $177,13^{*}$ & 313,72 & 438,28 \\
IPB CH-F & $93,00^{*}$ & $163,44^{*}$ & 258,26 & 368,15 \\
IPB CH-G & 38,14 & 67,00 & 220,86 & 284,76 \\
IPB CH-H & 58,73 & 86,93 & 308,41 & 383,04 \\
IPB CH-I & 55,73 & 79,20 & 355,00 & 418,40 \\
IPB CH-J & 56,15 & 69,54 & 158,97 & 172,70 \\
IPB CH-K & $71,33^{*}$ & $102,60^{*}$ & 310,10 & 369,32 \\
IPB CH-L & 51,07 & 78,93 & 332,21 & 395,12 \\
IPB CH-M & 50,40 & 63,87 & 308,94 & 345,64 \\
IPB CH-O & 8,27 & 9,80 & $11,51 *$ & $13,12^{*}$ \\
Hot Chilli & 26,73 & 50,00 & 297,96 & 397,04 \\
\hline
\end{tabular}

Keterangan: *= berbeda nyata terhadap varietas pembanding (Dunnet's taraf $5 \%$ )

\section{Seleksi Indeks Cabai Hibrida}

Hasil seleksi berdasarkan indeksi seleksi beberapa karakter daya hasil dan komponen hasil menghasilkan urutan 14 cabai hibrida uji dari cabai hibrida uji yang memiliki nilai total indeks seleksi terendah sampai tertinggi berturut-turut adalah IPB CH-O, IPB CH-D, IPB CH-J, IPB CH-F, IPB CH-C, IPB CH-E, IPB CH-G, IPB CH-B, IPB CH-K, IPB CH-H, IPB CH-A, IPB CH-L, IPB CH-M dan IPB CH-I (Tabel 6).

Tabel 6. Indeks seleksi terboboti dari empat belas cabai hibrida

\begin{tabular}{|c|c|c|c|c|c|c|c|c|c|}
\hline Karakter & JBLP & BBLP & JBT & BBT & $\mathrm{B}$ & $\mathrm{P}$ & $\mathrm{D}$ & \multirow{2}{*}{ Total } & \multirow{2}{*}{ Peringkat } \\
\hline FP & 5 & 5 & 3 & 3 & 5 & 5 & 5 & & \\
\hline Hot Chilli & $-13,91$ & 4,95 & $-8,64$ & 4,20 & 58,54 & 34,22 & 49,08 & 128,44 & \\
\hline IPB CH-A & $-6,80$ & 1,36 & 0,77 & 3,58 & 27,63 & 22,14 & 17,49 & 66,17 & 4 \\
\hline IPB CH-B & 9,57 & $-1,53$ & 5,50 & $-0,88$ & 9,51 & 13,98 & $-14,20$ & 21,95 & 7 \\
\hline IPB CH-C & $-2,98$ & 3,34 & $-4,46$ & 0,37 & $-2,64$ & $-1,33$ & $-9,17$ & $-16,87$ & 10 \\
\hline IPB CH-D & $-2,27$ & $-16,85$ & $-5,29$ & $-10,66$ & $-38,04$ & $-35,66$ & $-27,06$ & $-135,83$ & 13 \\
\hline IPB CH-E & 21,56 & 6,56 & 22,8 & 6,23 & $-27,37$ & $-19,11$ & $-22,42$ & $-11,75$ & 9 \\
\hline IPB CH-F & 18,92 & 0,92 & 19,41 & 2,77 & $-33,66$ & $-28,73$ & $-21,75$ & $-42,12$ & 11 \\
\hline IPB CH-G & $-8,26$ & $-2,88$ & $-4,44$ & $-1,34$ & 8,87 & 25,72 & $-0,34$ & 17,33 & 8 \\
\hline IPB CH-H & 1,94 & 6,02 & 0,49 & 3,51 & 2,79 & 20,02 & 3,46 & 38,23 & 5 \\
\hline IPB CH-I & 0,91 & 21,51 & $-4,74$ & 17,50 & 30,74 & 13,43 & 63,50 & 142,85 & 1 \\
\hline IPB CH-J & 0,67 & $-9,17$ & $-3,81$ & $-6,87$ & $-31,53$ & $-35,66$ & $-16,66$ & $-103,03$ & 12 \\
\hline IPB CH-K & 8,18 & 6,19 & 4,37 & 2,83 & 7,91 & 6,83 & $-3,58$ & 32,73 & 6 \\
\hline IPB CH-L & $-1,85$ & 8,44 & $-1,49$ & 4,10 & 25,61 & 23,60 & 11,18 & 69,59 & 3 \\
\hline IPB CH-M & $-2,18$ & 6,07 & $-5,21$ & 1,66 & 24,65 & 14,32 & 32,53 & 71,84 & 2 \\
\hline IPB CH-O & $-46,10$ & $-48,32$ & $-61,95$ & $-49,14$ & $-95,26$ & $-94,12$ & $-60,60$ & $-455,49$ & 14 \\
\hline
\end{tabular}

Keterangan: $\mathrm{FP}=$ Faktor pembobot, JBLP $=$ Jumlah buah layak pasar, BBLP $=$ Bobot buah layak pasar, JBT $=$ Jumlah buah per tanaman, $\mathrm{BBT}=$ Bobot buah per tanaman, $\mathrm{B}=$ Bobot per buah, $\mathrm{P}=$ Panjang buah, $\mathrm{D}=$ Diameter buah 
Berdasarkan nilai total indeks seleksi, maka hanya diperoleh satu cabai hibrida yang memiliki total indeks seleksi lebih tinggi dibandingkan varietas pembanding Hot Chilli yaitu cabai hibrida IPB CH-I (Tabel 6). Hal ini menunjukkan bahwa hanya cabai hibrida IPB CH-I yang merupakan cabai hibrida yang layak diuji lebih lanjut sebagai persyaratan pelepasan varietas cabai hibrida.

\section{KESIMPULAN}

Beberapa cabai hibrida yang diuji memiliki karakter pertumbuhan dan daya hasil yang setara atau lebih baik dibandingkan varietas pembanding Hot Chilli. Berdasarkan karakter bobot buah per tanaman dan bobot buah layak, maka seluruh cabai hibrida yang diuji (kecuali IPB CH-D dan IPB $\mathrm{CH}-\mathrm{O})$ sudah setara dengan varietas pembanding. Namun demikian, berdasarkan nilai total indeks seleksi hanya IPB $\mathrm{CH}-\mathrm{I}$ yang dapat dilanjutkan untuk diuji keunggulan sebagai persyaratan pelepasan varietas.

\section{DAFTAR PUSTAKA}

BPS dan Direktorat Jenderal Hortikultura. 2016. Produksi, Luas Panen, dan Produktivitas Sayuran di Indonesia. http://www.pertanian.go.id/Indikator/tabel-2-prodlspn-prodvitas-horti.pdf. [25 September 2016].

Daryanto, A., S. Sujiprihati, M. Syukur. 2010. Heterosis dan daya gabung karakter agronomi cabai (Capsicum annuиm L.) hasil persilangan diallel. J. Agron. Indonesia. 38(2):113-121.

Falconer, D.S., T.F.C. Mackay. 1996. Introduction to Quantitative Genetics. 4th edition. Longman. Essex. $356 \mathrm{p}$.

Grinberg, M., Perl-Treves, R. Palevsky, E. Shomer, I. dan Soroker, V. 2005. Interaction between cucumber mosaic plants and the broad mite, Polyphagotarsonemus latus: from damage to defense gene expression. The Netherlands Entomol Soc. Entomologia Experimentalis et Applicata. 115(1):135-144.

Hapsari, R.T. 2014. Pendugaan keragaman genetik dan korelasi antara komponen hasil kacang hijau berumur genjah. Buletin Plasma Nutfah. 20(2):51-58.

Kementerian Pertanian RI. 2016. Harga komoditas pangan minggu ini. http://panelhargabkp.pertanian. go.id/2016/. [25 September 2016].
Mantri, S.M. 2006. Heterosis and combining ability studies for quality parameter and yield in chili (Capsicum annuum L.). Thesis. Dharwad. Department of Genetic and Plant Breeding, College of Agriculture, University of Agricultural Sciences.

Mejaya, I.M.J., A. Krisnawati, H. Kuswantoro. 2010. Identifikasi plasma nutfah kedelai berumur genjah dan berdaya hasil tinggi. Buletin Plasma Nutfah. 16(2):113-117.

Rommahdi, M., A. Soegianto, N. Basuki. 2015. Keragaman fenotipik generasi F2 empat cabai hibrida (Capsicum annuum L.) pada lahan organik. Jurnal Produksi Tanaman. 3(4):259-268.

Sujiprihati S, R. Yunianti, M. Syukur, Undang. 2007. Pendugaan nilai heterosis dan daya gabung beberapa komponen hasil pada persilangan diallel penuh enam genotipe cabai (Capsicum annuum L.). BulAgron. 35(1):28-35.

Suntoyo, L. Octariana, Fatria, D. Hendri, Kuswandi. 2015. Evaluasi pertumbuhan dan hasil beberapa papaya hibrida di wilayah pengembangan Bogor. J. Hort. 25(3):193-200.

Sutjahjo, S.H., Rustikawati, A.W.S.S. Gumabo. 2007. Kajian genetik dan seleksi genotipe S5 kacang hijau (Vigna radiata) menuju kultivar berdaya hasil tinggi dan serempak panen. Agrin. 11(1):10-18.

Syukur, M., S. Sujiprihati, R. Yunianti, D.A. Kusumah. 2010a. Evaluasi daya hasil cabai hibrida dan daya adaptasinya di empat lokasi dalam dua tahun. J. Agron. Indonesia 38(1):43 - 51 .

Syukur, M., S. Sujiprihati, R. Yunianti, K. Nida. 2010 b. Pendugaan komponen ragam, heritabilitas, dan korelasi untuk menentukan kriteria seleksi cabai. J. Hort. Indonesia. 1(2):74-80.

Syukur, M., S. Sujiprihati, R.Yunianti. 2012. Teknik Pemuliaan Tanaman. Penebar Swadaya. Jakarta.

Yunianti, R., S. Sastrosumarjo, S. Sujiprihati, M. Surahman, S. H. Hidayat. 2010. Kriteria seleksi untuk perakitan varietas cabai tahan Phytophthora capsici Leonian. J. Agron. Indonesia. 38(2):122-129. 